Crime, Histoire \& Sociétés / Crime, History \& Societies

Vol. 21, $n^{\circ} 2$ | 2017

L'histoire de la criminalité et de la justice pénale : propositions de recherche pour le $21^{\mathrm{e}}$ siècle

\title{
Future Research Agendas for the History of Crime and Criminal Justice in China
}

Thomas Buoye

\section{(2) OpenEdition \\ Journals}

Electronic version

URL: http://journals.openedition.org/chs/1880

DOI: $10.4000 /$ chs. 1880

ISSN: 1663-4837

\section{Publisher}

Librairie Droz

\section{Printed version}

Date of publication: 31 December 2017

Number of pages: 195-204

ISSN: $1422-0857$

\section{Electronic reference}

Thomas Buoye, "Future Research Agendas for the History of Crime and Criminal Justice in China", Crime, Histoire \& Sociétés / Crime, History \& Societies [Online], Vol. 21, n² | 2017, Online since 19 July 2020, connection on 16 January 2021. URL: http://journals.openedition.org/chs/1880 ; DOI: https:// doi.org/10.4000/chs. 1880 


\title{
Future Research Agendas for the History of Crime and Criminal Justice in China
}

\author{
Thomas Buoye
}

$\mathrm{O}$ ver the past decade the digitization of historical archives and the growth of international scholarly collaboration in Chinese legal and social history has created a wellspring for future research agendas that scholars have only begun to tap. The availability online of nearly a quarter of a million separate reports of capital crimes for the Qing dynasty (1644-1911) held by the First Historical Archives in Beijing ${ }^{1}$ and the creation of an electronic index to search these records will fuel wideranging studies of crime and criminal justice for the foreseeable future. Concurrently, the internet has created venues for an unparalleled range of international and interdisciplinary scholarly collaboration. Perhaps the single most important website is Legalizing Space in $\mathrm{China}^{2}$. Endowed by the French National Agency for Research (ANR), the website provides open access online to collections of judicial cases, imperial legal codes and commentaries, administrative regulations, as well as handbooks and treatises that were intended for use by Qing judicial officials. This website has quickly become an essential resource for legal historians ${ }^{3}$ and, equally important, it has established a permanent forum where scholars from Asia, Europe, and North America are engaged in a joint effort to translate the all-important substatutes of the Qing code. Although scholars have had access to documents at the Number One Historical Archives since the 1980s and although many of the materials available on the Legalizing Space in China website can be found in the larger East Asian Libraries, the convenience of the digitization and electronic indexing of many of these resources and their availability on internet platforms have opened new vistas for the study of the history of crime and criminal justice in China.

1 The First Historical Archives has been the repository for most legal records of the Qing Dynasty; my references to digitized documents refer to their database, which is available on site in Beijing. In addition to the collections in Beijing, in the 1980s the Family History Library in Salt Lake City, Utah, acquired the archives of the Autumn Assizes, the annual review of capital cases in the Qing. These documents are available on microfilm around the world via local Family History Centers and there is a searchable index on-line. The Modern History Institute at the Academia Sinica in Taipei has also obtained a major portion of the routine memorials of the Board of Punishments, capital cases related to marriage and sex offenses; these documents are available on site in Taipei. The Institute of Philology at the Academia Sinica and the National Palace Museum in Tapei also has websites with indexes to historical databases that include documents relevant to the history of crime and criminal justice. In addition to these resources there are several other local archives in China and Taiwan that various scholars have utilized for legal history. Local archives have certain advantages and disadvantages vis-a-vis central archives but space does not permit a more detailed discussion of the relative merits of these sources. See Ye Wa and Joseph W. Esherick, Chinese Archives: An Introductory Guide.

2 http://lsc.chineselegalculture.org/.

3 For recent develops in Chinese legal history see Chenjun You (2013, p.165-202).

Crime, Histoire \& Sociétés / Crime, History \& Societies 2017, vol. 21, n² 2, pp. 195-204. 
The availability of individual criminal case records is fundamental, but in order to advance the study of crime and criminal justice we will also need to address longstanding misperceptions regarding the Qing law code (Da Qing lïli 大清律例). For this reason the importance of the effort to translate the substatutes of the Qing law code cannot be overstated and to that end Legalizing Space in China is an essential intellectual enterprise. Continually revised to address an array of social, economic, and administrative issues, the substatutes of the Qing law code serves as a detailed roadmap to the legal, ideological, social, and political cross currents that shaped late imperial judicial history. Beginning in the eighteenth century the code was revised and reissued at five year intervals. Each permutation furnishes scholars with a snapshot of the concerns that informed legislative action. Furthermore, the contemporary commentaries on the code supply critical insights into the evolving Qing jurisprudence and the ongoing official debates over crime and social order. The translation and explication of the Qing substatutes along with the digitization of criminal cases records will allow researchers to reconstruct the history of crime in the context of the evolving administrative superstructure of the Qing criminal justice system. The legislative embodiment of official debates related to crime, the substatutes illustrated the incremental and protracted struggle of the Qing judiciary to respond to the unintended consequences of unprecedented population growth and an increasingly commercialized economy that stoked social unrest beginning in the eighteenth century.

One can readily discern the potential impact of the digitization of archival sources to transform the scholarly landscape by comparing two studies that bookend the last twenty five years of the history of crime in China: the late Philip Kuhn's masterpiece of social history, Soulstealers ${ }^{4}$ and a recent path breaking statistical analysis of crime by Chinese scholars, Zhiwu Chen, Kaixiang Peng, and Lijun Zhu, "Social-economic Change and its Impact on Violence: Homicide History of Qing China"s. Although vastly different in their research methodologies and historical range, both studies primarily relied on the resources of the First Historical Archives in Beijing. Rooted in a year-long research stint at the Number One Historical Archives ${ }^{6}$, Kuhn's work marked the beginning of a new era in historical research that began when foreign historians were granted access to the archives in the 1980s. Prior to the opening of Chinese archives, most foreign scholars had focused on larger scale collective events, such as religiously inspired uprisings, secret society activities, clan feuding and other criminal activities that received attention in published sources such as dynastic histories or provincial gazetteers. In contrast, Kuhn focused on an eighteenthcentury sorcery scare that the Qianlong emperor (r. 1736-1795) used as a pretext for an extensive crackdown on crime and a politically charged shakeup of provincial bureaucrats who the emperor felt were lax enforcers of social order. Reconstructing an empire-wide campaign to root out alleged sorcerers who allegedly stole the souls of young boys by clipping their queues, Kuhn masterfully revealed the complex politics of criminal justice in the context of the socioeconomic changes of eighteenth-century

Kuhn (1992).

Chen et al. (2017, p.8-25).

6 As a graduate student my stint in the Number One Archives overlapped with his and I can personally attest to Philip Kuhn's generosity as a mentor and his dedication as a scholar. All of us who have followed in his footsteps owe Professor Kuhn a deep debt of gratitude for using his tact, charm, and diplomacy to further the cause of international scholarly collaboration at the First Historical Archives. 
China as well as the political dilemmas that the ethnically Manchu emperors faced in ruling their predominately Han Chinese empire. Combining social science theory with rich accounts of local events and trenchant insights into bureaucratic politics and imperial prerogatives, Soulstealers set a new standard for historical research of crime and society in late imperial China; it also served as a model for future scholars who would use central government documents to study crime in the context of eighteenthcentury social and economic changes.

Over the past decade the digitization of major collections at the Number One Archives has dramatically expanded opportunities for developing research agendas. Simultaneously, thanks to the scholarly exchanges of the past few decades, a new generation of Chinese scholars who have had opportunities to study abroad have brought fresh perspectives and new methodologies to the historical study of Chinese crime and criminal justice. The recent article in Explorations in Economic History, "Social-economic Change and its Impact on Violence: Homicide History of Qing China," by Zhiwu Chen, Kaixiang Peng, and Lijun Zhu is the first scholarly publication in English (the authors have published several articles in Chinese journals) to exploit fully the digitization of the 242,803 reports of capital crimes. As a historian who began working in the archives in the pre-digital age I stand in awe of the scale and the scope of this research. Those of us in the first generation of foreign scholars to work in the First Historical Archives relied on simple handwritten catalogues to identify relevant documents. Hunting through bundles of original documents by hand, pioneering researchers were allowed to handle original documents before any major collections had been microfilmed. While the process was arduous and time consuming this type of exposure to the collections also revealed the physical condition of the documents, disclosed lacunae in historical coverage, and serendipitously exposed researchers to cases that would have been omitted in an electronic keyword search. Equally importantly, wading through large numbers of documents, which were catalogued only by year, imparted a sense for the overwhelming burden that the annual review of capital crimes imposed on eighteenth-century judicial officials.

According to Chen, Peng, and Zhu's quantitative analysis of homicide cases records and reports of major crimes, the homicide rate rose steadily throughout the eighteenth century but it gradually declined over the course of the nineteenth century. With an annual rate ranging between 0.35 and 1.47 per 100,000 inhabitants during the 1661-1898 period ${ }^{7}$ homicide rates were comparatively low in China. Rates this low would not be seen in Western Europe until the late nineteenth century, but, based on my reading of eighteenth century materials, the increase in homicide and violent crime was perceptible and worrisome to eighteenth-century officials. In my opinion, the apparent decline in homicide rates in nineteenth century is more problematic. Even though the authors' statistical analysis of population density, state capacity, local self-governance, interregional grain market integration, and grain price level as significant drivers of the homicide rate in eighteenth and nineteenth centuries is impressive and initially persuasive, as a Qing historian I worry that the sources for eighteenth and nineteenth century China are not comparable due to changes in reporting and procedures in the criminal justice system that began in the early nineteenth century. While I respect the methodology and intellectual ingenuity of the research, I suspect that the gradual decline in violence after 1821 may reflect

Chen et al. (2017, p.8-25). 
declining efficiency in the administration of criminal justice as well as changes in criminal procedures rather than real declines in violent crime and personal security. Recent qualitative studies of crime in the eighteenth and nineteenth centuries by Robert Antony and Matthew Sommer, both veterans of research in the First Historical Archives, have found serious discrepancies in the interpretation and enforcement of the law between local and central government judicial officials beginning in the eighteenth century and continuing, if not accelerating, in the nineteenth century ${ }^{8}$. Similarly, my own research on the "legislative turn" in Qing rule has shown that the adjudication of capital crimes and the annual review of provisional death sentences underwent significant revisions during the eighteenth century. For example, the continuous expansion of death-penalty eligible crimes, which was meant to deter violent crime, in practice increased the volume of death-penalty eligible cases under annual review and threatened to overwhelm the elaborate multi-tiered reviews of capital crimes and provisional death sentences. Thus, I am skeptical that the decline in the number of case records for the nineteenth century necessarily represented a real decline in violence; rather, I suspect that it may have been due to expanded use of summary executions, which were reported differently, and a rise in vigilantism later in the nineteenth century. That said, the work of Chen, Peng, and Zhu is nonetheless trailblazing and one hopes to see more soon from these very talented scholars.

At the risk of oversimplifying, the contrast between the qualitative historical work of Philip Kuhn and the quantitative analysis of Chen, Peng, and Zhu illustrates the opportunities and pitfalls that might arise from the digitization of archival document and the ease of access of the internet. Clearly, many scholars in China and abroad are cognizant of the pitfalls and prospects that digitization entails. Indeed, sensitivity to the potential hazards of large scale quantitative analysis of historical resources has become a recent topic of debate in China as it has been for decades in the West. A recent issue of The Qing History Journal (清史研究) included five articles addressing digitization of local archives, metadata, data mining and the future of quantitative research ${ }^{9}$. While Chen, Peng, and Zhu were knowledgeable and sensitive to historical context, in the hands of less skilled researchers, the ease of access to digitized sources may entail the risk of statistically sound but historically questionable conclusions if we do not promote close collaboration among the disciplines. Optimistically, the creation of internet fora for scholarly communication and the sharing of research methodologies will engage scholars representing a wider variety of social science disciplines.

Given the staggering volume of documents now available where should we begin? For practical, historical, and intellectual reasons the starting point for future studies of crime and criminal justice should be the eighteenth century. The unprecedented eighteenth-century legislative turn in Qing rule was inextricably linked to the unprecedented demographic growth and increasingly commercialized economy

8 See Sommer (2015). Based on a study of 1200 legal cases from local and central court archives, Sommer finds that desperate poverty drove the rural poor into a variety unconventional survival strategies, including polyandry. Over time grass-roots judicial officials apparently became more tolerant of polyandry despite its illegality. Antony (2016) uses archival sources as well as field research. His research reveals growing vigilantism and the increasing use of summary executions at the provincial and local levels of judicial administration. Both practices would have led to an uderreporting of violent crime in routine memorials to the central government.

$9 \quad$ Qing shi yanjiu $(2016,4)$. 
that produced a more competitive and contentious society that was reflected in the quadrupling of substatutes during the eighteenth century. For reasons that we do not yet fully understand, the legislative turn in Qing rule notably slowed after the early nineteenth century. While much research remains to be done, the outbreak of large scale uprisings and rebellions in the nineteenth century at a minimum at the least suggests that the new substatutes had not fully eliminated the underlying causes of violent crime and social distress. Finally, because the extant records are most abundant and richest in detail for this period there is a practical argument for a focus on the eighteenth century. In fact, an analysis of the changes in the content and narrative style of criminal case records over the course of the eighteenth century reveals initial signs of stress in the Qing judiciary. Equally troubling was the enormous backlog of capital cases awaiting final sentencing and the related phenomena of deaths in detention and exile to Xinjiang that bespoke a growing crisis in the criminal justice system.

As a way of proposing a possible agenda for future research let me offer an example from my own work on homicides related to acts of sodomy (jijian 雞姦) ${ }^{10}$. Consulting resources available on the Legalizing Space in China website we discover that the substatutes related to sodomy were appended or modified during the eighteenth or early nineteenth centuries when the legislative crackdown on violent crime was in full swing. Consistent with most eighteenth-century provisions, the legislation primarily aimed at stemming interpersonal violence, with four of the five regulations targeting violent sexual assaults. These substatutes applied more severe penalties for a variety of aggravating circumstances and one provision notably required beheading when the victim of sexual molestation was under the age of ten. From previous research on the topic we know that the Qing code ultimately contained five substatutes that addressed sodomy ${ }^{11}$. Interestingly, only one substatute addressed consensual homosexual intercourse. In fact, case records reveal that consensual anal intercourse only came to official attention in the context of a more serious violent crime and that sodomy was invariably treated as a minor offense. The fact that consensual homosexual intercourse was not actively prosecuted suggests to me that judicial officials were mainly concerned with suppressing violent behavior, not regulating sexual mores or condemning male homosexuality. Clearly, illicit sexual relations between males did not carry the stigma associated with the term sodomy in the West. While legislation and legal commentary provide valuable insights into judicial policy and official opinion regarding sodomy, these materials tell nothing about how the law was applied. To answer this question we need to examine specific cases.

A simple search on the Number One Historical Archives collection of 242,803 routine reports of capital crimes $^{12}$ using the Chinese legal term for sodomy locates

10 The use of the term sodomy is convenient but problematic. As some scholars have pointed out, translating the Chinese term for illicit anal intercourse between men, jijian (雞姦), which combines the characters for chicken and illicit sex, as sodomy can be misleading because most of the related substatutes addressed sexual assaults and were not meant to condemn male homosexuality, nor was the offense invested with comparable Western notion of sinfulness. Only one substatute punished consensual homosexual anal intercourse and there is little evidence that the law was rigorously enforced. In fact, the Chinese character for illicit sex was also used for illicit heterosexual intercourse. In fact, much of the vocabulary used to discuss illicit sex was the same regardless if it was homosexual or heterosexual.

11 Meijer (1985, p.109-133).

12 Routine memorials reporting capital crimes were sorted into three major categories: blows and afrays, 
3573 extant records for capital crimes, almost exclusively homicides, related to sodomy for the period of Qing rule. However, for a variety of reasons this number is deceptive. For example, the data base contains only five records of any capital crimes for the reigns of the first three emperors (1644-1723) which comprise the first eight decades of the dynasty. Furthermore, if one were to examine the 3573 documents by imperial reigns one would find that 1917, more than half of the extant cases, occurred during the sixty years of the Qianlong reign (1736-1795) (see appendix). The fact that more than half of the extant documents are from the final two-thirds of the eighteenth century when Chinese population doubled to reach an unprecedented level of over 300 million may be meaningful, but how can we explain the fact that there are few extant cases, only 1656, for the last seven reign periods (1796-1911)? In fact, there are fewer extant records of capital crime cases for the nineteenth century in general.

\section{Extant Routine Memorials Reporting Capital Crimes by Imperial Reign Periods}

\begin{tabular}{|l|c|c|}
\hline \multicolumn{1}{|c|}{ Reign Period } & All Capital Crimes & $\begin{array}{c}\text { Capital Crimes related to } \\
\text { Sodomy }\end{array}$ \\
\hline Shunzhi (1643-1661) & 0 & 0 \\
\hline Kangxi (1662-1722) & 0 & 0 \\
\hline Yongzheng (1723-1735) & 5 & 0 \\
\hline Qianlong (1736-1795) & 84,965 & 1917 \\
\hline Jiaqing (1796-1820) & 48,074 & 692 \\
\hline Daoguang (1821-1850) & 53,011 & 660 \\
\hline Xianfeng (1851-1861) & 11,704 & 89 \\
\hline Tongzhi (1862-1874) & 17,269 & 92 \\
\hline Guangxu (1875-1908) & 27,206 & 123 \\
\hline Xuantong (1909-11) & 0 & 0 \\
\hline Unknown & 569 & 3573 \\
\hline Total & 242,803 & 0 \\
\hline
\end{tabular}

Was the nineteenth century less violent - or less well documented? Obviously, using this collection for statistical analysis would be problematic but, assuming no systemic bias in reporting of violent crimes and that the losses to the collection were largely due to the vagaries of storage and preservation, at least we can compare extant cases of violent crimes related to illicit homosexual or heterosexual sex. Focusing solely on the Qianlong reign for which the databases contains 84,956 records of capital crimes, comparisons within this dataset may prove more meaningful. For example, there were 5049 extant cases of capital crimes related to illicit heterosexual sex but only 1917 extant cases of related to sodomy. Interestingly, the comparison is flawed because of the way the electronic index has been designed we can exclude

land and debt, and marriage and sex offenses. Only the latter two collections have been digitized. 
rapes from the category of illicit heterosexual sex, while the cases related to sodomy include consensual relationships as well as assaults.

With the digitization and electronic indexing of documents, doing simple statistical comparisons of extant case records, as well as determining the frequency of cases over time and by region, can be done in minutes with a few key strokes. Such information is informative and helpful but more importantly, to obtain a preliminary understanding of the case we can use the electronic index to review brief descriptions of the cases that were originally prepared by Qing officials. Ultimately, however, we must examine the complete case records carefully. Depending on the condition of the document and the complexity of the crime, these reports may run from twenty to fifty handwritten pages, but thanks to the strict bureaucratic requirements on uniform recordkeeping and established bureaucratic norms for reporting crime, every record provides the same basic information, including depositions, coroners reports, official summary of the case, citation of the applicable law, and a proposed sentence. Prior research into the nature of official reporting has demonstrated that the content of these reports were highly structured and that case narratives became highly routinized over time $^{13}$. The consistency in reporting and the indexing of cases, makes it possible to make a well-informed selection of cases for qualitative analysis of capital crimes.

For example, in killings related to sodomy a frequent scenario for violence occurred after a breakup and a jilted companion thought, sometimes mistakenly, that his erstwhile partner had begun a new liaison. Similarly, another fatal scenario unfolded when a younger partner, who apparently had taken up with his older partner for economic benefits, ended the relationship but the older partner continued to pursue the younger man. In other instances, violence erupted when an outraged senior male relative confronted the man who had been sodomizing his younger male relative. In this scenario the sexual relationship was often longstanding and consensual, but the older male relative acted out of personal moral outrage. Thus, a survey of criminal case reports quickly allows a researcher to identify a variety of familiar scenarios of sodomy related to capital crimes that also include economic exploitation, outright sexual assaults, and pedophilia. Interestingly, the scenarios of sodomy were very similar to those for capital crimes related to "illicit" consensual heterosexual relationships. In fact, the terms used to describe both homosexual and heterosexual relations were consonant. For example, the Chinese term commonly translated as adultery in English (姦) was used to describe cheating by a partner in both homosexual and heterosexual relationships.

While we must be cautious in our use of criminal case records of homicides to understand male homosexuality more broadly, even a preliminary reading of the archives indicates that homosexual relations were interwoven into everyday life in eighteenth-century China. In the case records we find individuals who were shopkeepers, craftsmen, workers, farmers, neighbors as well as beggars, itinerant laborers, and vagabonds. Sometimes sex was purchased, but just as often there were long term bonds and, while reporting was increasingly streamlined there are a few cases that poignantly recount genuine affection on the part of one, if not both partners. Overall, as in the case of heterosexual relationships, we find that jealously, exploitation, assault, and deception precipitated violence. While prior research has revealed official concern with the notorious "bare stick", the rootless, unmarried

13 Buoye (1995, p.95-130). 
males, the migrant laborers who were the common scapegoats for a variety of violent crimes, this preliminary dip into the archives indicates that in violent crimes related to sodomy the assailants were usually members of the local community and usually persons well known to their victims. Similarly, marginalized men, especially beggars and impoverished young men in the countryside, frequently appear in the criminal records as victims and perpetrators, but the only time I have found the "bare stick" substatute cited was when two tailors drugged a fifteen-year-old boy and raped him. This indicates that "bare stick" was a marker of blatant anti-social behavior instead of social status. The two tailors owned an established business and had sold clothing to their victim and his father on prior occasions. It seems clear that the application of the "bare stick" substatute which increased the severity of punishments was related to the premeditation and the use of drugs to render their victim helpless. More research needs to be done on the application of "bare stick" legislations but clearly it would be a mistake to consider the term simply shorthand for deracinated young males.

Much research on violent crime in China remains to be done, but based on my own reading of thousands of homicide cases, the sad fact seems to be that, whether it was a dispute over land ${ }^{14}$ or an act of illicit sex that precipitated a wrongful death, most, but by no means all, victims and perpetrators were otherwise ordinary people who were inadvertently caught up in unpremeditated violent events. Qing officials who adjudicated and reported capital crimes come across as judicial bureaucrats who reported the relevant details of incidents normally without editorializing or moralizing about the underlying causes of violence. Interestingly, official accounts of homosexual activity were not condemnatory or judgmental though in cases of rent defaults on land triggering violence we can find denunciations of greedy landlords who were punished for creating circumstances that led to a wrongful death. In capital crimes related to sodomy, the fact that the victim, perpetrator or both were engaged in a homosexual relationship was usually reported matter-of-factly in order to understand the motivation and circumstances of the more serious violent crime. Thus it would seem that the evidence from these cases contradicts received wisdom that the "Confucian" family system unequivocally condemned homosexual liaisons.

In a brief article one can hardly do justice to the all the excellent research on the history of crime and criminal justice in China. While the Qing documents I have discussed are of unmatched richness, there is no shortage of historical sources for many earlier periods in Chinese history. Obviously, studies of crime and the history of criminal justice will not be limited to the eighteenth century or to documents in the First Historical Archives. As noted above there are many other archival collections and there is no shortage of case compilations, legal codes or judicial commentary for earlier periods in Chinese history. Studies of crime and criminal justice in China have benefitted enormously from work done on Western societies and one hopes that these scholars will begin to incorporate and address recent scholarship by China specialists. Many of the findings will be familiar to scholars of the West, but others may have a distinctive Chinese twist. As the noted scholar of crime and banditry Robert Antony discovered during his fieldwork in a region known for being a "bandit nest" well into the 1930s, local villagers believed the crime was prevalent because the bandits controlled the fengshui. Finally, digitization and the internet have also facilitated scholarship on crime and criminal justice in the modern period. Funded by

14 Buoye (2000). 
the European Research Council, an international research team led by Daniel Lesse at the University of Freiburg has created The Maoist Legacy Project, which maintains a database of documents related to historical justice from the 1950s to the 1980s.

As in many fields of research the internet has greatly facilitated both formal and informal international scholarly collaborations. Like other fields of study, the history of crime and criminal justice in China has undergone a dramatic transformation over the past decade due to the digitization of sources and the internet. The opening of Chinese historical archives and the expansion of collaborations between Chinese and foreign scholars that began in the 1980s have fueled a generation of research that has directly and indirectly addressed important issues in the study of crime and criminal justice. Today within minutes a scholar can learn that there are 105 extant reports of individuals in Guangdong Province who were sentenced to the agonized "death by slicing" during the reign of the Qianlong emperor (1736-1795). Clearly, technology has created countless opportunities for research and only bureaucratic restrictions on accessing and copying materials place limits on what scholars might accomplish in the future. The combination of primary source materials that vividly depict the everyday struggles of the common people, and worldwide scholarly cooperation to translate the most dynamic elements of the Qing code, has created the potential for detailed historical studies of one of the world's most sophisticated criminal justice systems that will deepen our understanding of the history of crime in China and will provide an important foundation for comparative studies of crime, law, and judicial practice.

Thomas Buoye University of Tulsa Chapman Hall, 800 S Tucker Tulsa, OK 74104, USA thomas-buoye@utulsa.edu

\section{BIBLIOGRAPHY}

Antony, R.J. (2016) Unruly People: Crime, Community, and State in Late Imperial South China, Hong Kong: Hong Kong University Press.

Buoye, T. (1995) Suddenly Murderous Intent Arose: Bureaucratization and Benevolence in Eighteenth Century Qing Homicide Reports, Late Imperial China, 16, 2, p.95-130.

Buoye, T. (2000) Manslaughter, Markets, and Moral Economy: Violent Disputes over Property Rights in Eighteenth-Century China, Cambridge: Cambridge University Press.

Chen, Z., Peng, K. and Zhu, L. (2017) Social-economic Change and its Impact on Violence: Homicide History of Qing China, Explorations in Economic History, 63, p.8-25.

Kuhn, P. (1992) Soulstealers, Cambridge MA: Harvard University Press.

Meijer, M.J. (1985) Homosexual Offences in Ch'ing Law, T'oung Pao, Second Series, 71, livr. $1 / 3$, p.109-133.

Sommer, M.H. (2015) Polyandry and Wife-Selling in Qing Dynasty China: Survival Strategies and Judicial Interventions, Oakland, CA: University of California Press.

You, Chenjun (2013) How a "New Legal History" Might Be Possible: Recent Trends in Chinese Legal History Studies in the United States and Their Implications, Modern China, 39, 2, p.165-202. 